\title{
Monitoring Infrastructure Policy Reforms and Rural Poverty Reduction in Ghana: The Case of Keta Sea Defence Project
}

\author{
Isioma U. Ile \\ Ewald Q. Garr \\ School of Government, University of the Western Cape \\ Wilfred I. Ukpere \\ Department of Industrial Psychology and People Management, Faculty of Management, \\ University of Johannesburg, Johannesburg, South Africa \\ E-mail: wikpere@uj.ac.za
}

Doi:10.5901/mjss.2014.v5n3p633

\begin{abstract}
Over the years Ghana has adopted many policy reforms with the aim of reducing poverty. Though official reports indicate reduction in poverty, poverty has become a rural phenomenon. An essential factor identified as crucial for rural poverty reduction is infrastructure. Though the government of Ghana has acknowledged the potential contribution of infrastructure to poverty reduction, and continues to increase annual expenditure on infrastructure provision, the government is worried about the failure of many infrastructure projects to reduce poverty. Since policies provide frameworks that guide action, it would be expected that Ghana's infrastructure policies address these problems. The study explores the relationship between infrastructure and rural poverty reduction, and the adequacy of Ghana's infrastructure policy environment in contributing to rural poverty reduction.
\end{abstract}

Keywords: Infrastructure, Poverty Reduction, Rural Communities, Public Policy, Implementation, Targeting, Integrated Development, Participation, Financing Infrastructure, Impact Assessment.

\section{Infrastructure Provision and Rural Poverty Reduction in Ghana}

Ghana is a developing country in sub-Sahara Africa with a 2008 per capita income (PCI) of US\$670 (World Bank, 2009). Over the years Ghana has taken various reforms aimed at poverty reduction. Though some measure of poverty reduction has been achieved, poverty remains largely a rural phenomenon (GoG, 2007:25; GSS, 2006: entire report). With about $60 \%$ of the population living in rural communities of which over 50\% are poor (Obeng-Odoom, 2007:3). It is important the country's poverty reduction strategies pay attention to rural areas.

Infrastructure facilities like transport, electricity, water, irrigation, etc, have been identified as a major vehicle for poverty reduction (OECD, 2006:1-40, DFID, 2002:6-13). In rural areas where about 75\% of the poor live, there are very limited or no basic infrastructure facilities. Consequently, production and living costs are high, and there is limited access to social services. There is less opportunity for development, and poverty is perpetuated in a form of a vicious cycle (IFAD, 2008:1; Gunatilaka, 1999:1). It would follow then that if poverty is to be reduced there is the need to provide basic infrastructure facilities in rural communities. Similarly, many scholars have argued that poverty reduction in Ghana and sub-Sahara Africa would depend on providing efficient infrastructure facilities (Ariyo and Jerome, 2004:3; Fan, 2004:1).

Despite the optimism about the significant contribution of infrastructure to poverty reduction, it has not always been the case. Some scholars have concluded that infrastructure does not benefit the poor, a view that characterized the 1980s. Similarly, DFID (2002:14) observes that:

....Benefits have often been less than anticipated, especially because of inadequate attention to governance and institutional frameworks. 'White elephant' infrastructure projects are far from unknown. And high levels of personal and political corruption, facilitated by weak systems, have hindered a demand-led approach, distorted public investment choices, diverted benefits from the poor and encouraged neglect of maintenance.

This position was re-echoed when the government of Ghana $(G \circ G)$ noted that infrastructure provision in Ghana has not contributed much to poverty reduction as expected (Ministry of Finance and Economic Planning, 2009:2-4). Ghana's medium term annual infrastructure gap is estimated at US\$ 2.4 billion (ibid), and though annually Ghana 
increases its budgetary spending on infrastructure provision, Ghana is dotted with many uncompleted, abandoned, and failed infrastructure projects. Similar to the concerns of GoG, Engineers without boarders (EWB) noted as part of their projects in Ghana that infrastructure provision in Ghana is not guided by strategic frameworks but one driven by personal and political interest thereby resulting in "poor prioritization of infrastructure projects throughout rural Ghana". ${ }^{1}$ Kalitsi (1970: 224 - 225) also observed in a study of the resettlement project of Ghana's Akosombo dam "a resettlement programme which was largely expected to be of lasting benefit to the affected people presented now, only a cost in human suffering in spite of considerable public investment that was made."

Mutahaba, et al. (1993:44-48) points out that, poverty reduction or development should not only be about infrastructure provision but the framework that guides its provision, as many development projects in Africa that have failed because of inadequacies in policy management. Infrastructure provision in Ghana is done through sectoral policies: transportation policy, water policy, national electrification scheme, environmental policy, etc. These are complemented with national legislations like the national constitution, National Development Framework, Ghana Poverty Reduction Strategy (GPRS) I and II. Aside from sectoral policies Ghana has no broad policy for infrastructure provision.

The question then is why do these projects fail, and how can infrastructure projects be designed to reduce rural poverty? This question comes at the time when the GoG has admitted that there are problems with infrastructure provision ranging from funding, distribution, access, quality, management and maintenance of infrastructure: and has called for new ideas to improve infrastructure provision (Ministry of Finance and Economic Planning, 2009:2-3).

To understand the situation of infrastructure provision and poverty reduction in Ghana, the thesis assesses the relationship between infrastructure and poverty reduction, and examines the adequacy of Ghana's infrastructure provision policy environment. To empirically analyse these issues, a large-scale infrastructure project (costing about US\$ 1 billion) known as the Keta sea defence project (KSDP) initiated by the government of Ghana as a development project to save the rural communities of Keta from sea erosion, and to reduce poverty in these rural communities is examined as the case of the study.

\section{Hypotheses}

The study is guided by the following hypotheses:

1. There is a positive relationship between infrastructure (the KSDP) and rural poverty reduction.

2. The more an infrastructure project is guided by an infrastructure policy the more likely it is to succeed in reducing rural poverty.

\section{Objectives of the Study}

The main objective of the study is to establish a relationship between infrastructure and rural poverty reduction, and the implications for Ghana's infrastructure policy environment. This is pursued through the following sub-objectives:

1. Examine the role of infrastructure in rural poverty reduction

2. Explore the nature of policies that govern infrastructure provision in Ghana

3. Evaluate the impact of the KSDP on the affected people

4. Analyse the challenges, complexities, and opportunities inherent in the KSDP

5. Propose recommendations

\section{Methodology}

The study employed methodological triangulation, a combination of quantitative and qualitative methods, and various theories to analyse its data. Data was collected through primary sources such as survey questionnaires and interviews, and secondary sources such as project documents, government documents, and books.

\subsection{The case study}

After a century of continuous sea erosion, by 1996 more than half of Keta and its surrounding rural communities have been submerged. The sea and the lagoon were flowing into each other with some communities almost cut off from main

1 Internet source: http://www.ewb.ca/en/whatwedo/overseas/projects/infrastructure_ghana.html [4/4/2010] 
land. The loss of lands and buildings, destruction of the little infrastructure available, the decline in fishing, farming and other forms of livelihood led to increased poverty in the affected communities. As part of the Government of Ghana (GoG)'s intervention a US\$ 1 billion Keta Sea Defence Project was vigorously pursued from 1996 and completed in 2004. The project was designed as an integrated development project with the objectives; to stop sea erosion and flooding; and to reduce the high level of poverty in the affected rural communities. Consequently the project included the following components; Sea defence wall to stop sea erosion, create a safe enclave to revitalize the fishing industry, and to promote tourism; Flood control to reduce flooding of communities and farms, and to help increase agriculture production; Resettlement communities made-up of houses, electricity, water, and sanitation facilities; and an Asphalt link road through the communities to promote trade, and the development of local industries (GLDD, 2002:1-2).

\subsection{Method of Assessment}

\subsubsection{Infrastructure and Poverty Reduction}

Baseline data for poverty in the project communities was not available. To explore the relationship between infrastructure and poverty reduction the "with and without" approach was used to measure changes in poverty. The "with and without" approach allows for comparism of the study group to a control group where the differences between the two groups form the basis for inferring project impact. For the control group to form the baseline for assessing the project it had social, economic, geographical, historical and environmental features comparable to the study group but without an infrastructure project which makes the difference. Keta and Ada represented the study and control groups respectively. The study took note of the inevitable challenge of attribution bias and measures were taken to reduce its adverse effect on the findings.

\subsubsection{Ghana's Infrastructure Provision Policy Environment}

To examine the adequacy of Ghana's infrastructure provision policy environment and its implications on rural poverty reduction, a set of standard criteria was derived. The criteria included policy framework or level, policy content, financing, equitable distribution, monitoring and evaluation, environmental protection, targeting, accessibility and affordability, integrated development planning, impact on social wellbeing, impact on productivity and growth, job creation, management and maintenance.

\subsection{Sampling Method}

Accidental and Quota (non-probability) sampling methods were used to administer household survey questionnaires to 120 respondents (60 to each group, the study and control groups). The target group representing the affected people included: traders, fishers, farmers, and people employed in the formal sector. The questionnaire had questions on income and economic resources, prices of goods and services, health, education, drinking water, sanitation, shelter, security and vulnerability, and environmental sustainability. Three key officials on the KSDP from the District, Ministry of Works and Housing, and Parliament were also interviewed.

\subsection{Data collection and analysis}

Trained field workers (graduates from the communities) joined the researcher to administer the household questionnaires. The purpose of the survey was explained to the affected people. For each household a breadwinner responded to the questionnaire. Ewe and Dangme (local languages) were used where there were literacy challenges. The researcher held interviews with the key officials. SPSS (statistical package for the social sciences) was used to analyse the data.

\section{Ethical Statement}

The study ensured the confidentiality of participants. The purpose of the study was explained to the respondents. They were encouraged to freely decide if they wanted to respond to questions on the topic under study. The questionnaires were also made anonymous to prevent any possibility of tracing respondents to their responses. 


\section{Related Studies, Debates, and Theoretical Framework}

To clarify the concepts and to build-up the arguments, the paper reviews related works.

\subsection{Poverty in Ghana}

Ghana has a $2008 \mathrm{PCl}$ of US $\$ 670$ (World Bank, 2009). Since the 1980s the country has embarked on many rounds of development reforms; Structural Adjustment Programmes, Economic recovery programmes, Vision 2020, and now GPRS I and II. The 2006 Ghana Living Standard Survey indicates a decline in poverty (population living on less than US\$ 2 per day) from 51.7\% in 1991/92 to $28.5 \%$ in 2005/2006. The extreme poverty (population living on less than US\$ 1 per day) declined from 36.5\% in 1991/92 to18.2\% in 2005/2006 (GoG 2007:25). Despite the reported decline in poverty levels over the past 15 years, poverty remains largely a rural phenomenon (Aryee and Asante, 2003:4). According to a Ghana statistical service (2000) report, for 1999 urban poverty stood at $19 \%$ and rural poverty at 50\%. Also, given that the majority of Ghanaians 60\% live in rural areas (Obeng-Odoom, 2007:3), it follows reason that if Ghana is to reduce poverty it is important to pay significant attention to rural poverty reduction.

\subsection{Infrastructure, Growth and Poverty Reduction}

Infrastructure, generally categorised into economic and social infrastructure refers to,

physical facilities [roads, water and waste disposal systems, energy, market, irrigation, sea defence, flood controls, houses, health care and education communication systems, etc], and the services [transport, water and sanitation, energy, trade, relief and security, shelter, health care, education, information, etc.] flowing through those facilities (Masika and Baden, 1997:2).

Many theories have argued that infrastructure forms part of the capital stock (investment) of an economy that stimulates growth, and economic growth contributes to poverty reduction (DFID, 2002:4). The growth theories advance that infrastructure as capital is a factor of production that goes into the aggregate production function where growth is the effect of productivity (Straub, 2008:7). The Standard Production Function explains that the output of an economy or firm depends on the amount of input, which includes infrastructure capital. Thus, an increase in infrastructure capital stock would increase the productivity of other factors leading to growth (Straub, 2006:16). The "trickle down model" then assumes that increase in growth would result in benefits through employment opportunities, higher incomes, more goods and services at affordable prices and eventually reducing poverty (Jaillilan and Wess, 2004:2). However, this macro perspective may not be effective for rural poverty reduction as the poor are not targeted, instead, it could lead to such benefits accruing to the elites and the well-to-do in society. Since the poor refers to particular groups of people and individuals, rural poverty reduction should be approached from the micro level where the poor are targeted. Approaching rural poverty reduction from a micro-economic perspective, the paper considers how infrastructure affects households via income, prices of goods and services and other dimensions (access to health care, education, drinking water, electricity, shelter, sanitation, security, and environment).

As notably indicated by (Straub, 2008:7-8), Infrastructure can lead to higher productivity of other factors of production, and this translates into more jobs and high income. Similarly, Infrastructure affects prices through labour and output productivity, economies of scale, and cost adjustment. Lower prices make it possible for the poor to afford their basic needs. Infrastructure improves access to, health (World Bank, 2007:5), education (Porter, 2007:2-3), drinking water and sanitation - globally over 10 million people (mostly rural) die annually from water and sanitation diseases such as diarrhoea, cholera, dysentery, typhoid, heptatis, and tapeworms (UN, 2005: 3-8). This multi-dimensional approach applauded also by Sen (1990:88-90) allows for a holistic understanding of poverty and the factors that underpin it capabilities and deprivation.

The welfare economics theory offers a framework for the analysis of relationships between infrastructure projects and poverty. The welfare theory by heuristic extension originated from the Utilitarianism works of Jeremy Bentham (17481832) and James Mill (1773-1836). The theory argues that human welfare or benefits can be measured from the consumption of goods and services. The theory is also used to evaluate and to make policy decisions on the effect of projects on the welfare of affected people. Jenkins (1990:1, see Parsons 1996:46) remarkably notes that, if policy analysis refers to a "set of techniques with which to evaluate public policy options and select amongst them" then welfare economics theory provide the "analytical paradigm" for public policy analysis. Similarly, Mishan (1969:130) argue that 
welfare economics postulate among alternative economic situations in society, one makes people "better-off or worseoff." Under the theory income method explains project effects on beneficiaries in the form of increased productivity using producer surplus and cost savings using consumer surplus. The household theory explains welfare effect of project on poverty reduction in the form of consumers' utilities.

\subsection{Public Policy}

The state or the government as conceptualised by Thomas Hobbes (1651) in his works on the "leviathan" and "social contact" has the responsibility to provide for the welfare of her citizens. Explaining the role of the government further Thomas Jefferson emphasized that the state and its institutions are "human constructs" designed for the welfare of society, ie, "Governments are instituted by men...to secure the right of life, liberty, and pursuit of happiness" (Garr, 2010:4; Sachs, 2005: 348). The constitution of Ghana mandates the state to provide for the welfare of all citizens, and the resources of the country are to be used for this sole purpose ... "the sovereignty of Ghana resides in the people of Ghana in whose name and for whose welfare the powers of government are to be exercised ..." (Rep. of Ghana, 1992, Act. 1).

Public Policies are frameworks used by the state to meet the needs of her citizens. Baker et al. (1975:12-15) defines policy as "a mechanism employed to realise societal goals and to allocate resources." Similarly, Nolan (2002:91) defines policy as "a broad statement of principles to guide action. It sets forth an overall goal or direction, describes in general terms what should be done [to attain the goals]". It was not until the late 1980s when public policy studies took interest in infrastructure provision after infrastructure re-emerged into the international development arena as a purposeful vehicle for poverty reduction (OECD, 2006:3). According to Ariyo and Jerome these developments in infrastructure has brought about changes in the design, implementation, finance, ownership, management, and control of infrastructure services in both developed and developing countries (2004: 4). There is a shift from hardware to outcome based infrastructure, and a move from direct state provision of infrastructure to public private and community involvement. Fox and Porco (2001:106) note that infrastructure may be key to development but to accomplish this, it should be part of a "well structured program" [policy]. Similarly, DFID (2002:14) observes that for most infrastructure projects "...benefits have been less than anticipated, especially because of inadequate attention to governance and institutional frameworks..." These observations suggest that for infrastructure to contribute significantly to poverty reduction it should follow a well-laid-out policy framework.

\subsection{Sectoral and Generic Policies}

Infrastructure provision in Ghana is done through sectoral policies. However, the use of sector wide approaches (SWAP) may not contribute significantly to poverty reduction, as sectors that are likely to gain would support specific SWAPs, and sectors that do not gain directly may not support SWAPs (Maxwell, 2003:13; Foster et al., 2001:10). For cross-sectoral issues like poverty and rural development, generic (cross-sectoral) policies or regulations are the key determinants of outcomes. Unequivocally, Marden and Bristow (2004:456) write, "there is little specific knowledge of the degree to which sectoral policies could potentially be more integrated as to better match the holistic nature of rural areas." A cogent argument is that unlike sectoral policies many of which are characterised by inconsistencies and multiplicity of interpretations, generic policies are better placed to harmonize the development goals of the various sectors to meet national aspirations. It may be argued that a generic infrastructure policy may not be able to capture the diverse needs of the various sectors (Fox and Porco, 2001:120, 127). However it should be noted that most infrastructure services have at their base similar characteristics and concerns: high initial fixed cost and low marginal cost of supply, high sunk costs, public goods, and also involves externalities. As a result of these characteristics most infrastructures are subject to similar, funding arrangements, implementation strategy, and they may also fail or succeed for almost the same reasons. Definitely a generic infrastructure cannot make provision for everything but the key frameworks can be provided and the other details put in complementary policies. In addition to the specific facts of Ghana, evidence from most OECD countries has shown the enormous contributions of such generic infrastructure policies to efficient infrastructure provision and improvement in the wellbeing of their citizens (NZIER 2005).

\subsection{Critical policy concerns of rural infrastructure provision}

As rightly noted by Masika and Baden (1997:4), rural infrastructure provision has not benefited the poor as expected. 
Ineffective targeting and problems of affordability and accessibility have resulted in projects for the poor benefiting the well-to-do and not the poor (Gunatilaka, 1999:3). There is the need for effective targeting and the consideration of the income levels of project beneficiaries, the use of cross-subsidies, and price regulations can enhance the poor's access to infrastructure services. Integrated development planning, single-sector infrastructure projects make it difficult to realize meaningful impact on poverty reduction (DFID, 2002:11). Infrastructure projects complemented by other sectoral projects have greater impact on poverty reduction: eg. a road project linked to the productive sectors (eg. agriculture) creates forward and backward linkages in the production sector or social services. Financing is another challenge, most projects have failed because of lack of financing or poor financial arrangements. Most rural infrastructures are public goods and they attract limited funds from the private sector, they have to compete with viable sectors of the state for the limited public funds. Employment creation, though infrastructure has the capacity to create jobs and skills training opportunities for the rural poor (Fox and Porco, 2001:112), in most cases this opportunity is not harnessed. The DFID (2002:12) estimates that in Ghana if $30 \%$ of infrastructure projects were labour-intensive about 50,000 direct and 75,000 indirect jobs would be created. Environment, some infrastructure projects destroy the environment which serves as a life support for the rural people. Integrating environmental concerns into infrastructure provision helps to improve the wellbeing of the rural poor. Participation, most rural infrastructure projects have failed to address the concerns of the rural poor because these projects provide little or no room for affected people to participate. As noted by Williams (2005:63), the participation of the local people makes for effective targeting and integration of local knowledge to help improve the impact of such projects on the rural poor.

\subsection{Complexities in translating infrastructure policy in desirable outcomes}

Bardach (1977:5) cautions "even the most robust policy - one that is well designed to survive the implementation process - will tend to go awry. The classic symptoms of underperformance, delays, and escalating costs are bound to appear." Translating policy and plans into outcomes is the policy phase known as implementation. The importance of the implementation process is expressed in the notable statement of De Coning (an African public policy scholar) "successful implementation is the final acid test for a policy to be successful". For, Jenkins (1978:203) it is "how change occurs". Thus, the implementation process is a crucial stage between policy and successful outcome. There are three main models of implementation, the top-down, bottom-up, and the hybrid approaches. The top-down or rational systems approach is a centrally defined hierarchical system of implementation: the position is supported by Pressman and Wildavsky, 1973; Van Meter and Van Horn, 1975; Gunn, 1978; Mazimanian and Sabatier, 1983 (see Fischer et al, 2007:89). In sharp contrast to the top-down is the bottom-up approach which favour local or grassroot implementation: this position is championed by Lipsky 1971; Elmore, 1978; Hjern and Hull, 1982 (Fischer et al, 2007:89). The third model is the hybrid approach, a combination of the central and grassroot implementation. Remarkably, Hanf (1982:171) writes "it is not a question of choosing 'top' or 'down' as though these were mutually exclusive alternatives". The hybrid has proven much more effective in delivering desirable results than the other two extreme positions. This model is championed by Majone and Wildvasky, 1978; Lewis and Flynn, 1978; Barret and Fudge, 1981; Elmore, 1985; Sabatier, 1986; (see Fischer et al, 2007:91), and it has been applauded by scholars from the extreme positions.

There are three generations of implementation, the first known as the classical perspective, assumes a top-down approach, implementation is like a chain of commands from the top through the administrative machinery to specificity. Failures in implementation outcomes between the 1950s and 60s led to the emergence of the second generation which holds that implementation is complex and dynamics and it is not an automatic cog or machine. Despite the development in implementation body of knowledge with relevant case studies, theories of predictable causal relations have not been found; this gave rise to the third generation - searching for predictable theory of implementation (Bardach, 1977:5; Pressman and Wildavsky, 1977:3).

In this section, the paper uses some models to explain the relationships between policies and implemented outcomes. The impact chain model of James Austin (1990:77) describes how the concerns of society are converted into public policies which are then implemented through instruments like programmes and projects. The model assumes that a policy that is well planned, with the necessary consultation with the stakeholder and actors, and resources in place, should deliver the expected outcomes. In the case of the KSDP the model assumes that poverty is a major problem in Ghana and it is the result of economic, social, environmental, cultural and demographic factor. This relationship is illustrated in fig. 1 below. 
Fig. 1: Impact Chain Analysis: Relationship between policy and implemented project outcome

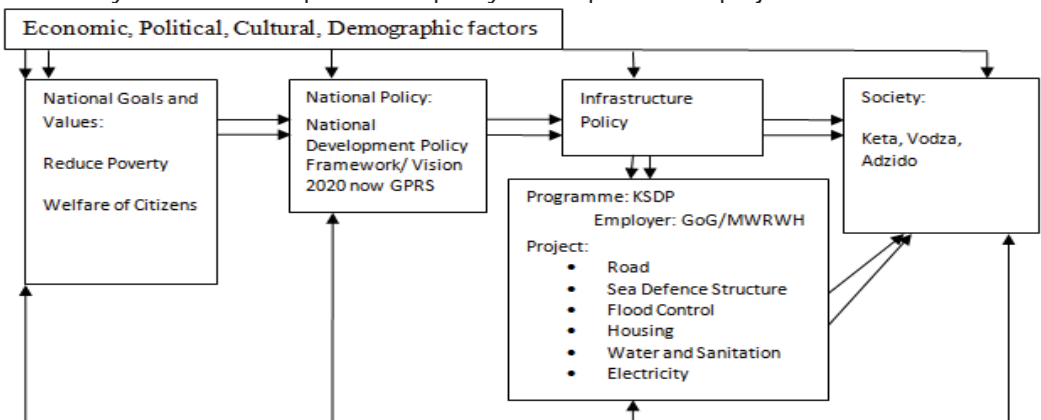

Source: Austin, 1990:77 (modified by author)

Ghana's desire to reduce poverty shapes the national goals and values which is translated into the national development framework or the GPRS. Assuming that Ghana has an infrastructure policy the goals of poverty reduction would reflect in the infrastructure policy and how infrastructure is provided. The KSDP is assumed to have been guided by the infrastructure policy. Under such a programme, there are a number of integrated projects intended to reduce poverty in the affected communities; road, sea defence structure, flood control, housing, electricity, water and sanitation. The beneficiary communities are Keta, Vodza, and Adzido. Based on the assumption of having a generic infrastructure policy, the impact chain concludes, that the more an infrastructure project is guided by an infrastructure policy the more likely it is to succeed in reducing rural poverty.

Departing from the impact chain model are Bardach (1977) and Warwick (1982) game models. The game models (Warwick, 1982, see Brynard and De Coning, 2006:193; Bardach, 1977:56) argue that, policies do not matter and that, policy implementation is a matter of power play; who gets what is based on what the government's expects to get in return. Implementation is a game of bargaining and manoeuvring, with each actor playing as much as possible to achieve their personal interests. In the case of the KSDP the government's initiation of the project can be seen as using the project to win votes, so the government may work hard to complete it. Another government taking over from the previous government, and having little political interest in the project area may decide to divert the project resources to elsewhere, and this can lead to the failure of the infrastructure project (KSDP). Here the emphasis is that policy may be important but politics can decide the faith of projects.

Whiles the impact chain model asserts that a coherent infrastructure policy is key to achieve rural poverty reduction, the game models calls that attention be paid to the role of political actors.

\section{Main Findings}

The main findings of the study are discussed and presented in the form of successes and failures.

\subsection{Successes}

The pre-financed infrastructure components made-up of the sea defence, flood control, and a link road have been completed. These account for some positive impacts on rural poverty reduction.

Income and Price changes: a large $68 \%$ of households reported marginal increases in income, and $32 \%$ reported no increases in income. Among ten basic goods, prices are comparatively lower, and this is attributed to the new asphalt road that has opened-up the rural communities to trade and enhanced mobility. As a confirmation of the welfare theory, household consumption (expenditure) increased by $71 \%$, leading to higher utility levels in the affected communities.

Access to health care has increased by about $86 \%$. This is due to higher enrolment in public health insurance, and improved access to transport. Access to education has increased by $82 \%$; this is attributed to improved access to transport. Level of security measured by the affected peoples' perception of their security indicates that feeling of security among the people has increased by over $100 \%$. This is due to the sea defence and flood control which protects the communities from erosion and flooding. Environmental sustainability measured via project documents and observation indicates that the environment which was almost destroyed (by the sea erosion and the flooding of the lagoon) is now protected. This is attributed to the sea defence wall and the flood control. Employing a pre-finance instrument for the core 
structural works was very efficient and this ensured that those components were completed on schedule. The prefinancing also ensured that the project had some level of protection from political manipulation.

The decision to make the project an integrated development project instead of a mere sea defence project is in tandem with Ghana's development aspiration to reduce poverty (GPRS).

The contract between the Government of Ghana and Great Lakes Docks and Company of the USA was well executed on the basis that the project components were completed on schedule. The project took cognizance of essential elements of project management also known as project management body of knowledge. Scope of project was specified, cost was pre-financed, time schedule was made drawn and followed, activity schedules were used to organize the project, components were integrated, the company had a news 'brief' (GLDD info) which communicated the objectives and progress of work, and also the key staff and their roles were specified.

\subsection{Failures}

Poverty Reduction: Beyond the infrastructure hardware the project failed to harness the development potentials and opportunities created. The fishing industry, tourism industry, or salt industry could have been targeted to add value to the project and the communities.

- The project failed to create jobs for the affected people, because it was mainly capital intensive and very little was done to ensure that local people got casual jobs

- Income levels are still low. The beneficiary communities have a PCI of US\$458 as against a national average $\mathrm{PCl}$ of US $\$ 670$.

- Resettlement component of the project has been abandoned.

- The project has failed to provide shelter for over 400 families. Even the houses provided so far fall short of what was promised in terms of size and the number of rooms.

- The affected people do not have electricity and majority do not have water.

- There are serious sanitation problems as over $70 \%$ of the people resort to open spaces in the absence of toilet facilities. This has serious repercussions on the peoples' health.

Financing: The choice of financing approach for the resettlement component of the project was inappropriate. Adequate budgetary provisions were not made for the project.

Political Manipulation: Political manipulation by the government (new government) disrupted the full implementation of the project. Hence the project was not completed and it was unable to significantly reduce poverty.

Participation of beneficiaries: This was weak and non-existent where it mattered most.

Private sector involvement: Private sector involvement in the project was limited. This is because the sectoral policy environment did not make adequate provision for the private sector.

Targeting, Affordability and Accessibility issues: These were not adequately considered and consequently it affected the ability of the project to contribute significantly to poverty reduction.

Integrated development planning: The effectiveness of the integrated development approach to the project was very minimal. Beyond the minimal impact of the completed physical infrastructure, very minimal or nothing has been achieved in the form of coordinated effort to develop services that can improve the standard of living of the people or create income earning opportunities for the people and this is a major problem with infrastructure provision in Ghana.

The reasons accounting for the problems with the project will not be complete without the mention of the implementation process. The coordination of the implementation process was hampered by the absence of a broad infrastructure policy. This was needed to coordinate the activities of the various sectors, and also to promote poverty reduction, growth and development. Ghana's sectoral approach to infrastructure provision is inadequate and lacking in many aspects (outlined above) and this is a major contributing factor to infrastructure failure in the country.

\subsection{Confirmation of hypotheses}

Though the project made some important contributions to rural poverty reduction, it was unable to sufficiently reduce rural poverty. This is attributed to the inadequacy of Ghana's infrastructure policy environment, where weak sectoral policies are used instead of a generic infrastructure policy. In view of these revelations:

1. The hypothesis that "there is a positive relationship between infrastructure (the KSDP) and rural poverty reduction" is confirmed.

2. The hypothesis that "the more an infrastructure project is guided by an infrastructure policy the more likely it is 
to succeed in reducing rural poverty" is also confirmed.

\section{Conclusion}

Infrastructure has the potentials to contribute significantly to rural poverty reduction. But this needs policy direction, deliberate planning, consultation with stakeholders, and implementation. Ghana's sectoral infrastructure provision environment is lacking in many policy areas, there is hardly any coherent framework that governs infrastructure provision. Hence Government's lamentation to the effect that infrastructure provision has failed to significantly contribute to poverty reduction (and growth) as expected. Based on these facts, the paper proposes a broad or generic infrastructure policy to serve as a coherent body of laws to govern infrastructure provision. In fig. 2 below is a model illustrating how such a policy reform in infrastructure provision in Ghana should be approached.

Fig. 2: A model for reform in Ghana's infrastructure policy environment

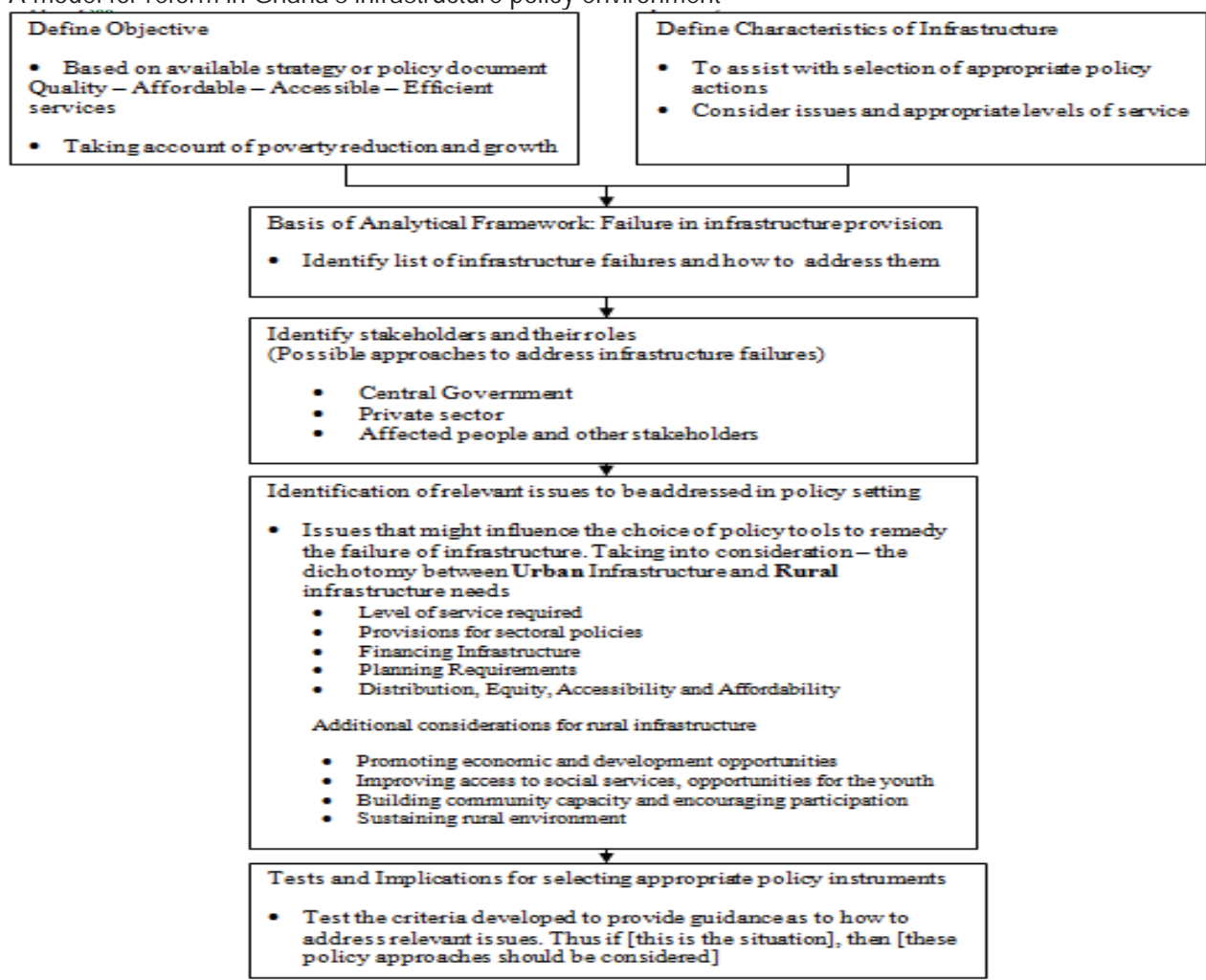

The reform process should identify the purpose of infrastructure provision for poverty reduction (and growth) in concurrence with the national development policy. The process should take note of differences in rural and urban areas, and the unique characteristic of infrastructure (high fixed and sunk costs, public goods, central operating network monopolies, externalities) to select appropriate policy actions. The process should continue to identify diverse cases of infrastructure failures and how to address them. The various stakeholders, their roles and levels of service should be identified. Additionally, the policy should identify financing options; take note of demographic and geographic factors, access to social services, affordability, job creation, and environmental protection. Generally, the approach for implementation should be based on transparent and robust cost-benefit analysis responsive to prevailing conditions. Evidence from OECD countries shows that reforms oriented toward generic infrastructure policies have promoted efficient, quality, reliable and affordable infrastructure services that have improved the public's welfare.

Like many developing countries Ghana's policy environment is still young as some sectors do not have comprehensive policies, or some policies do not adequately reflect national aspirations or respond to global trends. These are impacting negatively on national development. 
What the paper has done as a matter of relevance to national development is to identify one of these key areas, situate the opportunities and challenges and to make recommendations: specifically infrastructure provision and its impacts on Ghana's core goal of poverty reduction.

\section{References}

Ariyo, A. and Jerome, A. (2004). Infrastructure Reform and Poverty Reduction in Africa. Forum Paper, African Development and Poverty Reduction, Somerwest, SA, 13-15 October

Aryee, I. K. and Asante, F. (2003). Implementing a community-based poverty monitoring system in Ghana (2003-2006), MIMAP Research Paper.

Austin, J.E. (1990). Managing in developing countries: strategic analysis and operating techniques. New York: Free Press

Bardach, E (1977) The Implementation Game, MIT Press, Cambridge, Mass.

Baker, R.F., Micheals, R. M. and Prestons, E. S. (1975). Public Policy Development: Linking the technical and political processes. New York: John Wiley and Sons.

Brynard, P. and De Coning, C. (2006). Policy Implementation. Cloete, Wissink, and De Coning, (ed.) Improving public Policy: From Theory to Practice. Pretoria: Van Schaik: 180 - 213

DFID (2002). Making the Connections: Infrastructure for Poverty Reduction. London:DFID.

Fan, S. (2004). "Infrastructural and Pro-poor growth." Paper prepared for the OECD DAC POVNET Agriculture and Pro-Poor Growth, Helsinki Workshop, 17-18 June 2004

Fox, W.F. and Porca S. (2001) Investing in Rural Infrastructure. International Regional Scienece Review 24,(1):103 -133.

Fischer, F., Miller, G.J. and Sidney, M.S. (2007). Handbook of Public Policy: Theory, Politics, and Methods. Boca Raton, Fl: CRC Press

Garr, E. (2010) Achieving the MDGs in Ghana: Development Planning and Management processes. Unpublished paper. Cape Town: University of Western Cape

Ghana Statistical Service (2006) Ghana living Standard Survey. Accra:GSS

GLDD (2002). Keta Sea Defence Project. GLDD Info News. Available at http://www.gldd.com/images/Static/OurProjects_11_37-3.pdf [Accessed on $16 / 3 / 2009$ ]

Government of Ghana (2007). 'The Implementation of the Growth and Poverty Reduction Strategy (GPRS II), 2006 - 2009: 2007 Annual Progress Report', Accra, Ghana

Gunatilaka, R. (1999) Rural Infrastructure Programmes for Poverty Reduction. Paper prepared for the Regional Consultation on WDR2001 for South Asia, April 4-6, Rajendrapur,

Hanf, K. (1982). Regulatory structures: Enforcement as implementation. European Journal of Political Research, Vol. 10:159-72

IFAD (2001). Rural Poverty Report: the challenge of ending rural poverty Available at http://www.ifad.org/poverty/chapter1.pdf [Accessed on 15/04/2009]

Jenkins, W.I. (1978). Policy analysis: a political and organizational perspective. London: Martin Robertson

Kalitsi, E.A.K. (1970). Present and Future Problem of Administering Resettlement Towns. In: Chambers (ed), pp. 217-226

Masika, R. and Baden, S. (1997). Infrastructure and Poverty: A Gender Analysis. Report prepared for the Gender Equality Unit, Sida, BRIDGE Report No 51, Brighton: IDS

Marsden, T. and Bristow G. (2000). Progressing Integrated Rural Development: Framework for Assessing the Integrative Potential of Sectoral Policies. Regional Studies, 34(5):455-469

Maxwell, Simon (2003). "Heaven or hubris: reflections on the "New Poverty Agenda". Development Policy Review, 2003, 21 (1): 5-25.

Ministry of Finance and Economic Planning (2009). Report on the contribution of infrastructure to development. Accra: MFEP.

Mishan, E. J. (1969). Welfare Economics: Ten Introductory Essays. New York: Random House.

Mutahaba, G., Baguma, R. and Halfani, M. (1993). Viltalising African Public Adminstration for Recovery and Development. Connecticut: Kumarian Press.

New Zealand Ministry of Economic Development -NZMED (2005). Sustainable Economic Infrastructure: A Policy Framework. Wellington: NZMED

Nolan, R. (2002). Development Anthropology: Encounters in the Real World. Oxford: Westview

Obeng-Odoom, F. (2007). Enhancing Urban Productivity in Africa. Opticon 1826, Vol. 2, No. 1. Available at SSRN: http://ssrn.com/abstract=1032381 [Accessed on 16/07/2009]

OECD (2006) Promoting Pro-poor Growth Infrastructure. Paris: OECD Publishing.

Porter, G. (2007). Transport, (im)mobility and spatial poverty traps: issues for rural women and girl children in rural sub-Sahara Africa. A paper prepared for the international workshop 29 March, Stellenbosch, Overseas Development Institute.

Pressman, J. L. and Wildavsky, X. (1973). Implementation. Los Angeles: Uni. of Califonia Press.

Republic of Ghana (1992) The Constitution of Ghana, Act 1. Accra: Government Printer.

Sen, A. (1999). Development as Freedom. Oxford: Oxford University Press

UN (2005). Water for Life. New York: UN

Williams, J. J. (2005). Development planning and Citizenship in Cape Town. Development Southern Africa, Vol. 22, No. 1:46-65

World Bank (2009). World Development Indicator Database. Available at http://siteresources.worldbank.org/Datastatistics /Resources/GNIPC.pdf [Accessed on 22/01/2010] 